JSACE $2 / 25$

Revitalization of Wooden Apartments as a Tool to Deal with Shrinkage - Case Study from Valga

Received 2018/11/18

Accepted after revision

$2019 / 03 / 21$

\title{
Revitalization of Wooden
} Apartments as a Tool to Deal with Shrinkage - Case study from Valga

\section{Aime Ruus*, Jiri Tintera}

Tallinn University of Technology, School of Technology, Tartu College,

Puiestee 7851008 Tartu, Estonia

*Corresponding author: aime.ruus@taltech.ee

$\Gamma$ crossef $h t t p: / / d x . d o i . o r g / 10.5755 / j 01 . s a c e .25 .2 .22074$

Valga is a small shrinking town in South Estonia. The study focuses on the possibilities of solving the problems connected with apartment houses by using the disposition of apartments and improving energy efficiency to meet the contemporary standards of living space and getting buildings in public possession.

Keywords: shrinking cities, housing, urban brownfields, urban decline, post-soviet country, energy performance of buildings.

Valga is a small shrinking town in South Estonia on the border of Latvia. Valga has lost 33\% of its population since 1981 and $28 \%$ of the town territory is underused or abandoned.

There are 358 apartment buildings in Valga and 146 of them have wooden constructions. 22 wooden apartment buildings lie within the heritage conservation area (Fig. 1). Typical wooden apart-

Fig. 1

Schematic plan of Valga-Valka (Tintera et al. 2018)

\section{ktu

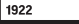

Journal of Sustainable Architecture and Civil Engineering Vol. 2 / No. 25 / 2019 pp. 16-24 DOI 10.5755/j01.sace.25.2.22074

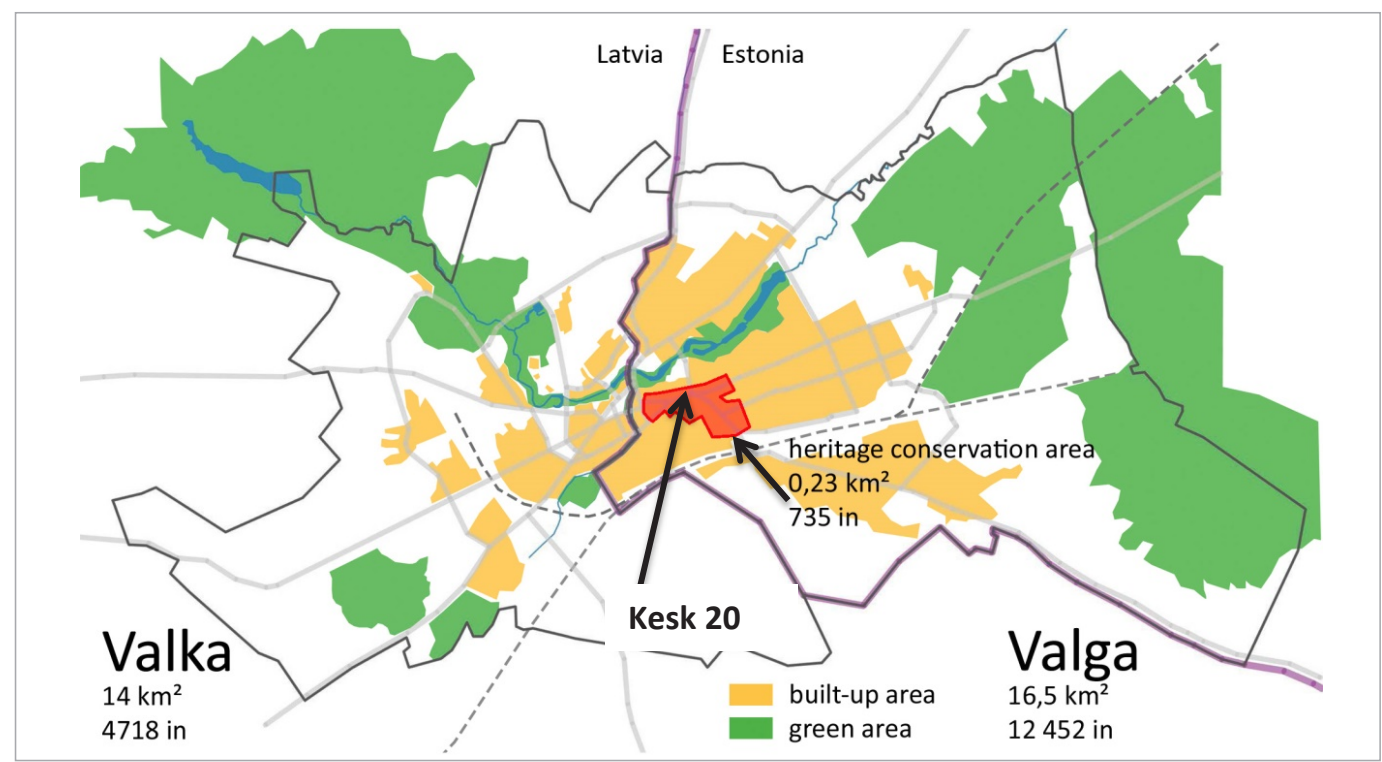


ment buildings have small apartments without bathrooms and with shared toilets in unheated areas. A large share of unused residential and business properties results in a fall in real estate prices. In 2017, the average price of a flat was less than 150 euros per square meter. A low price prevents owners from selling their properties and investment in housing is not lucrative for private sector. The result is the domination of low-quality living premises.

Six apartment buildings have been demolished in Valga during the last three years. The demolished buildings have been replaced with low-cost temporary public green areas. The residents would welcome even more rapid demolition works, however, this is delayed by the complicated ownership relations of the abandoned buildings. Still, not all the abandoned buildings should be demolished. The entirety of central Valga is a protected heritage site (Fig. 1) and it is complicated for demolition works to take place there. Also, abandoned buildings in other parts of the city are often of significant historic and architectural value and important elements of the urban landscape. To save at least some of these buildings from complete ruin, new uses must be found for them.

There are no high-quality rental flats on the market, even though there is no lack of demand. Both public institutions (the city government, the hospital, schools etc.) and entrepreneurs have been complaining about the lack of specialised labour. However, it is difficult to attract specialists to Valga because there are no high-quality living spaces on offer. To alleviate this problem that is hindering the city's development, the public sector - i.e. the local government with the help of the state - must interfere at least temporarily with the free market. From 2017 Ministry of Economic Affairs and Communications distributes investment for local governments to support housing development (Elamufondi arendamise investeeringutoetus...; Kohaliku omavalitsuse üksuse....)

The support may be up to $50 \%$ of the total project cost and is applied to municipal rental apartments - either new buildings or reconstruction. In this case the building has to be completely owned by the local government. The project does not have to be totally cost effective, otherwise the private sector will deal with the problem. Benefit will be a uniform city centre on the area of cultural heritage value enabling the mobility of specialists necessary in the area. Of course, the houses must be self-acting during the exploitation later. That is an important aspect for getting support - documents have to be prepared.

The paper examines on the case study of Kesk 20 apartment housing technical possibilities of building conversion on high quality rental premise.

The phenomenon of shrinking cities has been recently widely examined by scholars. Researchers concentrate on different aspects of urban shrinkage: economic (Bogataj, et al. 2016), social (Hollander and Németh 2011; Großmann, et.al. 2015; Ročak, et.al. 2016), impacts of shrinking population on land use (Kroll and Haase 2010; Chengbin and Ma 2015), and the challenges of urban governance of shrinking cities (Wiechmann 2008, Rhodes and Russo 2013). The term "shrinking city" is used for a city which is losing its population together with its economic importance (Reckien and Martinez-Fenandez 2011; Martinez-Fernandez et al. 2012; Kotilainen et al. 2015; Bernt, 2014; Sousa and Pinho 2015; Wiechmann and Bontje 2016). The main drivers of shrinkage as such are economic decline with job losses and out-migration, suburbanisation and natural population decline (Reckien and Martinez-Fenandez 2011; Martinez-Fernandez et al. 2012; Großmann et al. 2015; Haase, et al. 2016).

Urban shrinkage results in falling property values, over-dimensioned and underused infrastructure, social problems, out-migration, and waning social life and public spaces (Sousa and Pinho 2015). Two of the most prominent symptoms of shrinkage are housing vacancies and urban brownfields (Wiechmann and Pallagst 2012; Haase et al. 2016). The overcapacity of houses and the outdated state of maintenance cause the decrease of real estate values (Elzerman and Bontje 2015; Bernt, et al. 2017). The private sector is not interested in investing in renovating properties

\section{Causes and con- sequences of urban shrinkage}


or building new apartment buildings. The result is the predominantly low quality of residential premises and the lack of quality apartments. When the quality of life in an apartment building continues deteriorating, those who can do so move out. Apartment owners with the lowest income remain in the building, but they cannot afford to pay for maintenance and the building becomes uninhabitable (Prada-Trigo 2015).

The main problem with the owners in Valga is that there are a lot of different owners, some of them live abroad. Some buildings are in a condition which is not safe for living - the apartments are unusable and their real value is negative (need expenses to demolition or repair). There is very little demand on real estate market at all and no demand for that kind apartments. In that case the owner can gift the apartment to the local government. Some apartments are burdened with mortgages. In that case they cannot just gift their property and the local government must find a way how to manage the loans and mortgages.

There is (in reality mostly theoretical) possibility that an owner wants to remain an owner and keep the apartment but in that case all the expenses must be covered by them and that part of building is not the subject for support.

The local government cannot massively buy the apartments unless the building has architectural or cultural heritage value. Some residents have been relocated to other apartments in buildings in a better condition.

Today buildings must meet energy requirements and offer comfortable indoor environment. If they are on heritage conservation area, it is most important to offer comfortable indoor environment.

Air tightness is the biggest problem in older wooden buildings. Studies carried out in Tallinn University of Technology (Kalamees, et.al. 2011) found that the average values of air leakage rates for wooden apartment buildings was $\mathrm{q}_{50}=10 \mathrm{~m}^{3} /\left(\mathrm{hm}^{2}\right)$. Minimum and maximum values registered as 3.8 and $22 \mathrm{~m}^{3} /\left(\mathrm{hm}^{2}\right)$ accordingly. In brick and reinforced concrete panel buildings the average air leakage rate was only $4.0 \mathrm{~m}^{3} /\left(\mathrm{hm}^{2}\right)$. According to the minimum requirements for energy performance valid in 2018 (Hoone energiatõhususe miinimumnõuded) the average leakage rate of a building envelope may not exceed one cubic metre per hour and per square metre of the building envelope $\left(\mathrm{m}^{3} /\left(\mathrm{hm}^{2}\right)\right.$ and $1.5 \mathrm{~m}^{3} /\left(\mathrm{hm}^{2}\right)$ for energy calculations. In methodology for calculating the energy performance of buildings valid in 2018 (Hoone energiatõhususe arvutamise metoodika) base values (without measured air leakage rates) $3 \mathrm{~m}^{3} /\left(\mathrm{hm}^{2}\right)$ for new buildings and buildings after major renovation, and $6 \mathrm{~m}^{3} /\left(\mathrm{hm}^{2}\right)$ for existing and renovated buildings are given.

Material and methods

The paper looks at the case study of Kesk 20 wooden apartment buildings which has the problems described above (Fig. 2). The building technical condition is unsatisfactory, and the layouts of apartments inside has morally depreciated. Following the used measures: 1) changes in room dispositions, 2) improving energy efficiency, 3) the ownerships constrains have been described.

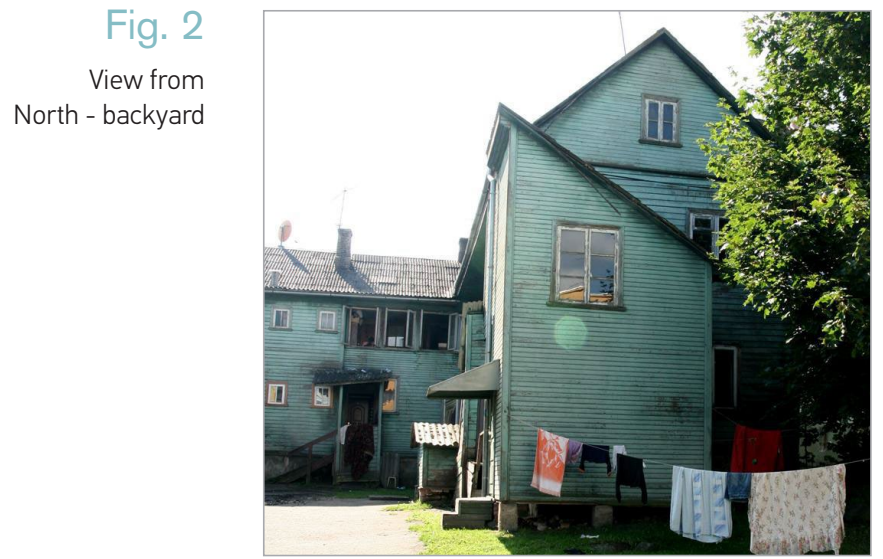

Kesk 20 was built in 1917 and is situated in the town centre of Valga. Most of its structures are made of timber - log as wall bearing construction and beams for floor and ceiling. Most of the rooms in the building have originally been planned as walk-through rooms (Fig. 3). Toilets and bathrooms are missing as the building is not connected to water and sewage network. The building used to have ten apartments (5 on the first floor) (Fig. 3). The apartments are equipped with stove heating and wood cookers, and the staircases are in unheated area. 


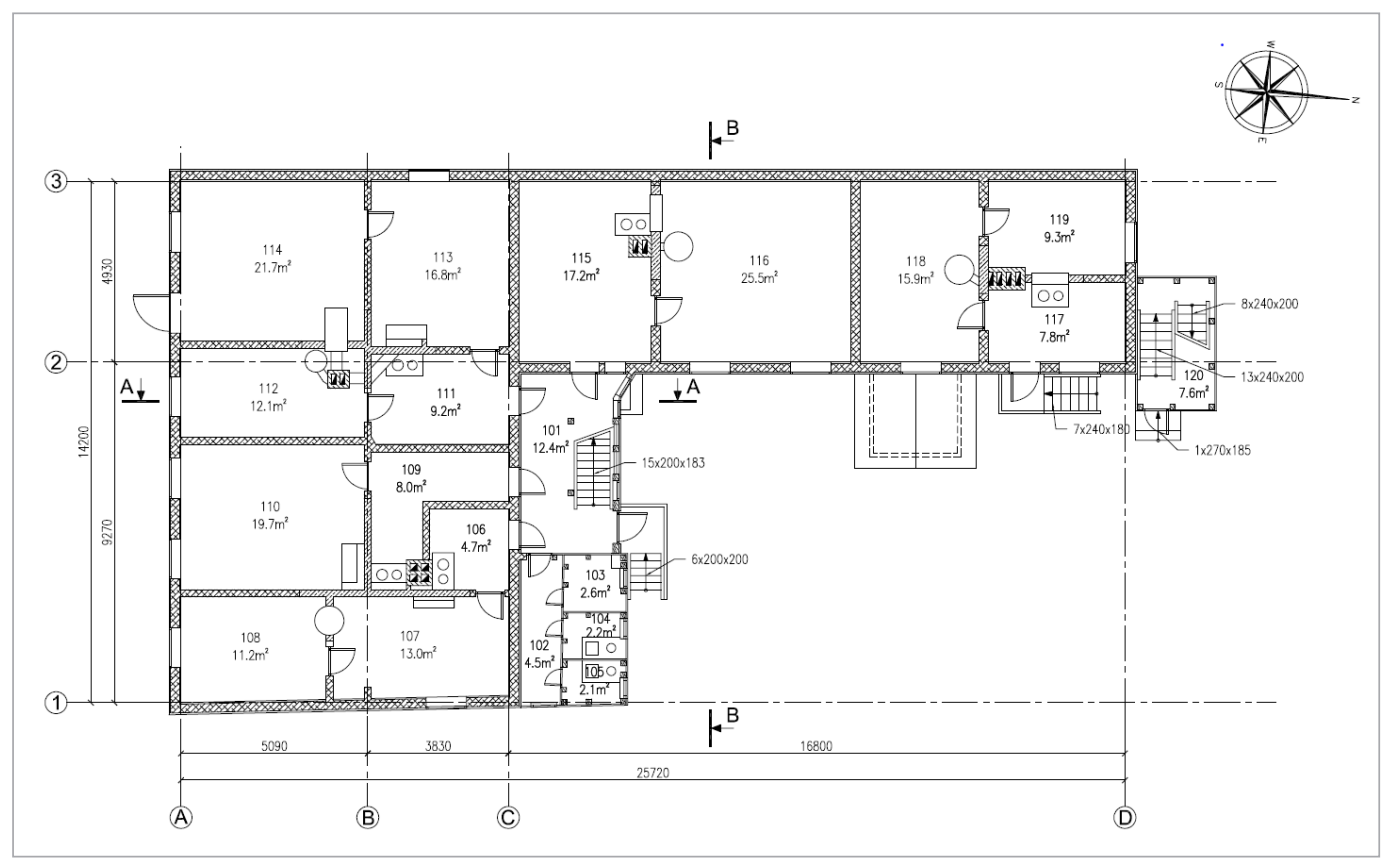

\section{Fig. 3}

Plan with initial planning of first floor (Pai 2015)

The building like other similar ones is inefficient in energy use. A log construction ( $240 \mathrm{~mm}$ ) without insulation offers approx. value $\mathrm{U}=0.5 \mathrm{~W} /\left(\mathrm{m}^{2} \mathrm{~K}\right.$ ) (EVS 908-1:2016). The ceilings and floors in that kind of buildings are often in a condition which is hard to estimate. A ceiling without any insulation or filling has $\mathrm{U}=1.36 \mathrm{~W} /\left(\mathrm{m}^{2} \mathrm{~K}\right)$, with porous filler (sawdust, peat, $\lambda=0.116 \mathrm{~W} /(\mathrm{mK})=0.10 \mathrm{kcal} / \mathrm{hm}^{\circ} \mathrm{C}$, Jürgenson, 1949) $\mathrm{U}=0.38 \mathrm{~W} /\left(\mathrm{m}^{2} \mathrm{~K}\right)$. Floor is a timber floor on dry sand $-\mathrm{U}=0.49 \mathrm{~W} /\left(\mathrm{m}^{2} \mathrm{~K}\right)$ if to take into account the values of $d r y$ sand $\left(\lambda=0.86 \mathrm{~W} /(\mathrm{mK})=0.75 \mathrm{kcal} / \mathrm{hm}^{\circ} \mathrm{C}\right.$; Jürgenson 1949) and $U=0.57$ $\mathrm{W} /\left(\mathrm{m}^{2} \mathrm{~K}\right)$ if to consider only ground $\lambda=2 \mathrm{~W} /(\mathrm{mK})$ (EVS-EN ISO 13370:2017).

The windows in the building need renovation or replacement. Minimum possibility is to repair the windows and improve the heat resistance by adding double glaze package and air tightness.

Energy simulation for whole building system energy performance was not performed because the idea was to concentrate on the borders and the building itself.

Total specific heat loss of the building envelope per square metre of heated area $\Sigma \mathrm{H} / \mathrm{A}_{\text {heated }} \mathrm{W} /$ $\left(\mathrm{m}^{2} \mathrm{~K}\right)$ can be calculated by formula 1 (Liginullenergia eluhooned):

$$
\sum H / A_{\text {heated }}=\frac{\sum U_{i} \cdot A_{i}+\sum \psi_{j} \cdot l_{j}+\sum \chi_{p} \cdot n_{p}+\rho_{a} \cdot c_{a} \cdot V_{\text {inf }}}{A_{\text {heated }}}
$$

where: $U_{i}$ is thermal transmittance of element of building envelope $\mathrm{W} /\left(\mathrm{m}^{2} \mathrm{~K}\right) ; A_{i}$ is area of element of building envelope $\mathrm{m}^{2} ; \psi_{j}$ is the thermal transmittance of the linear thermal bridge in $\mathrm{W} /(\mathrm{mK})$; $l_{j}$ is the length of the linear thermal bridge in metres; $x_{p}$ is the thermal transmittance of the point thermal bridge in $\mathrm{W} / \mathrm{K} ; n_{p}$ is the number of similar point thermal bridges in the building envelope; $\rho_{a}$ - air density, $1.2 \mathrm{~kg} / \mathrm{m}^{3} ; c_{a}$ - specific heat of air, $1.005 \mathrm{~kJ} /(\mathrm{kgK}) ; A_{\text {heated }}$ - heated area $\mathrm{m}^{2}$;

The infiltration air flow rate $\dot{V}_{\text {inf }}\left(\mathrm{m}^{3} / \mathrm{s}\right)$ is calculated by the means of the Formula 2:

$$
\dot{V}_{\text {inf }}=\frac{q_{50} \cdot A}{3600 \cdot X}
$$

where: $q_{50}$ is the average air leakage rate in $\mathrm{m}^{3} /\left(\mathrm{h} \cdot \mathrm{m}^{2}\right)$ of the building envelope; $A$ is the area of the building envelope (including floors) in $\mathrm{m}^{2} ; x$ is the factor which is 35 in the case of a single-storey building; 24 in the case of a two-storey building; 20 in the case of a three to five-storey building. 
The apartments in the building are privately owned and often co-owned which means that the building has dozens of owners. Two of the apartments are mortgaged, part of an insolvent estate, some of the owners live abroad. All this requires time-consuming and complicated negotiations to get apartments in public property.

Results and Discussion

Fig. 4

Facade of the building - view from South (Pai 2015)
The paper focuses on the revitalization of apartment buildings lying within the heritage conservation area of Valga town. Also, the paper presents architectural (Fig. 4) and technical solutions for building reconstruction. The reconstruction project (Pai 2015) designs 8 apartments ( 4 on the first floor) (Fig. 5). There will be one one-room, two two-roomed and one three-roomed apartment. The staircase will be indoors. The cold toilets will be demolished. The disposition of apartments

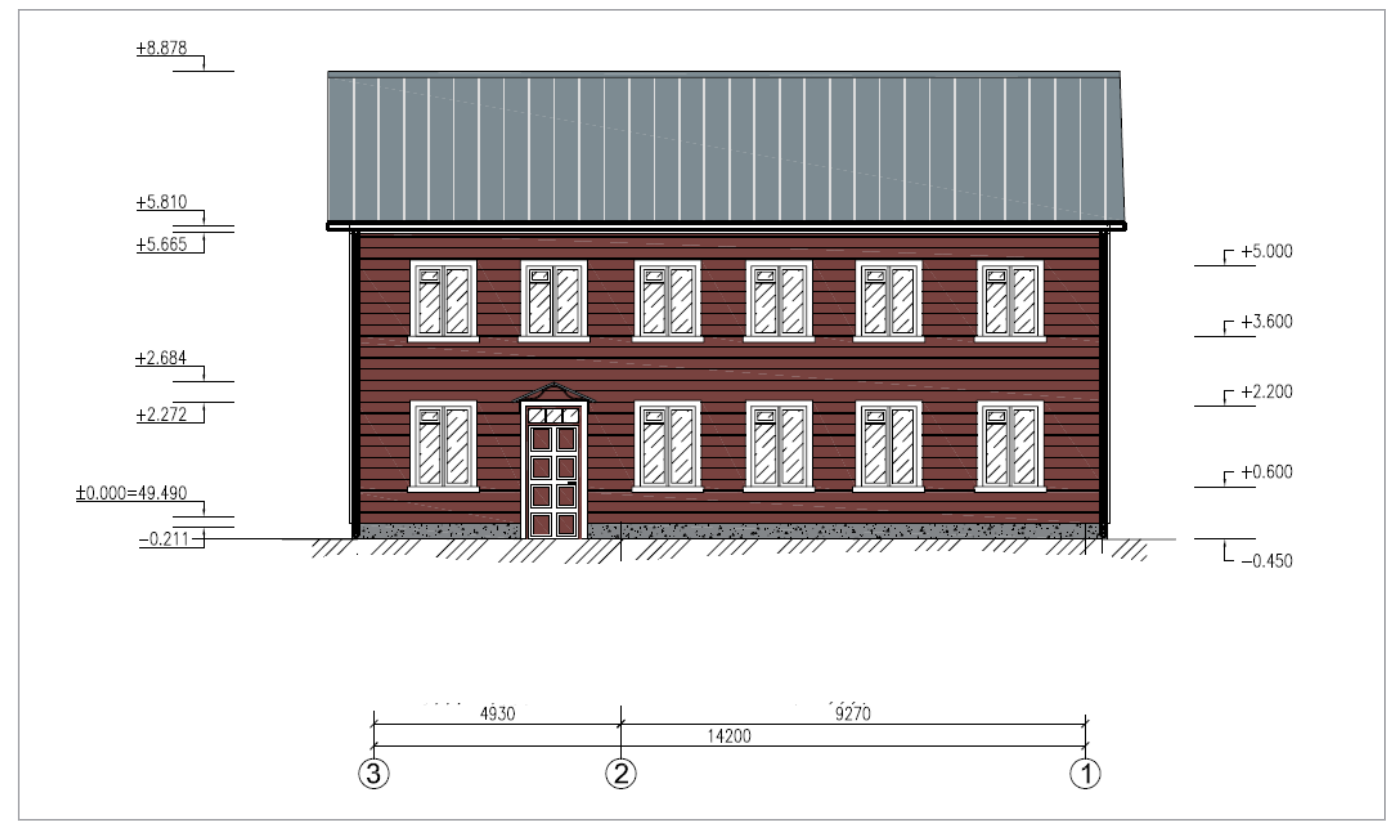

Fig. 5

Plan of the first floor after redesign

(Pai 2015)

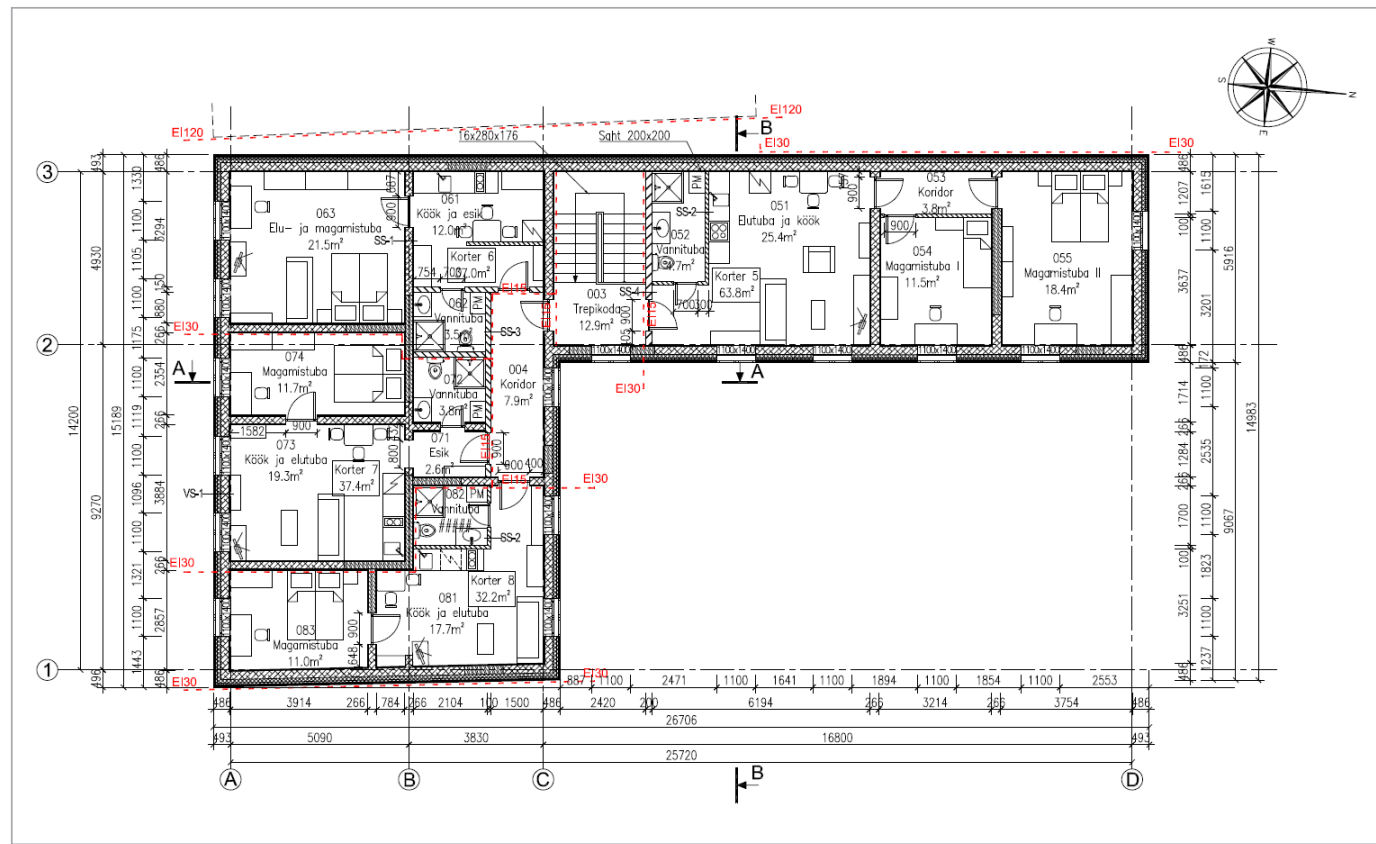


will be re-designed to meet the contemporary standards of living space. Additional exterior insulation is planned to be added (Fig. 6) and most importantly - the living environment will be modernized. There will be a comfortable private bathroom in every apartment.

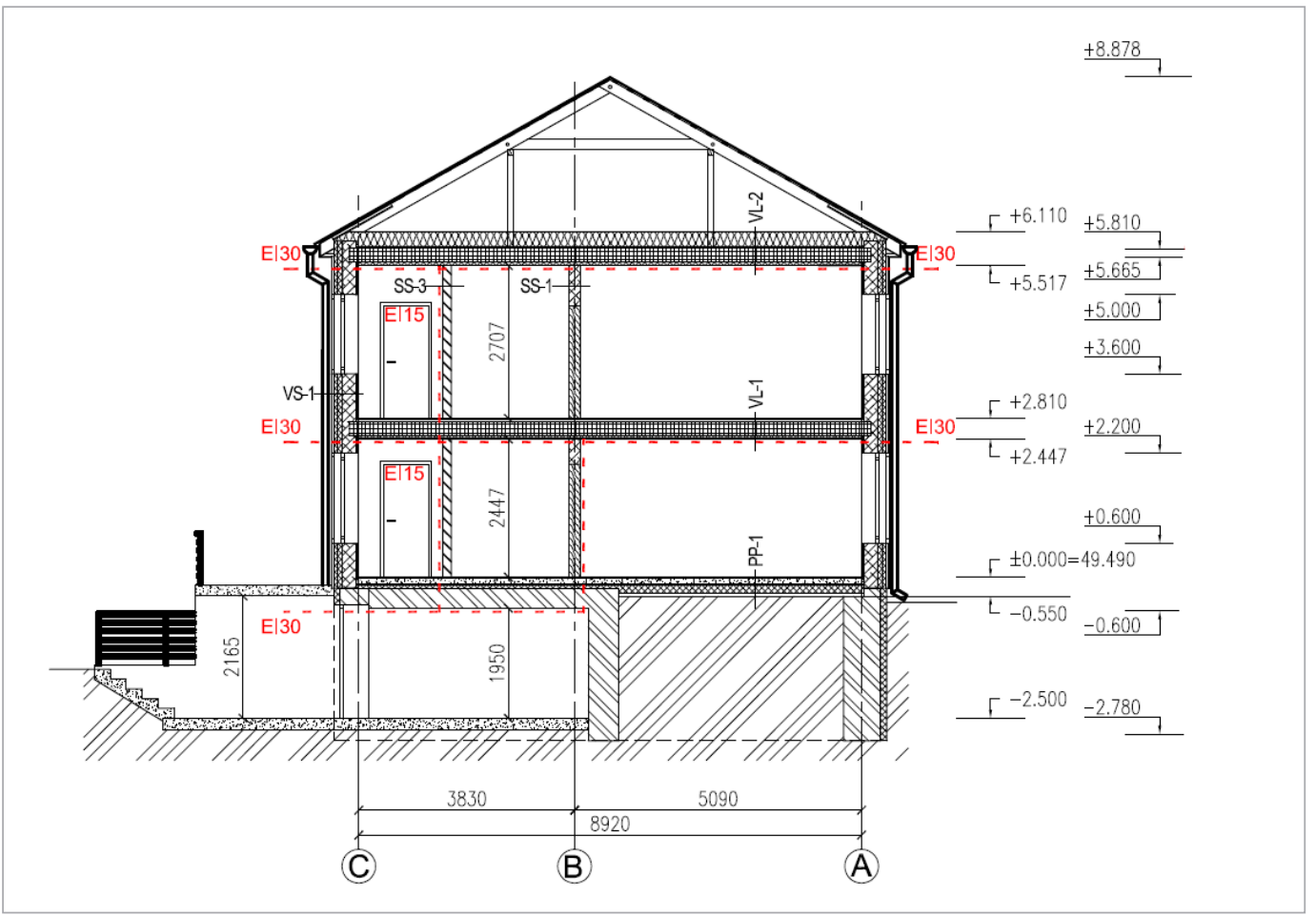

Fig. 6

Cross section of building (A-A on Fig. 5, Pai 2015)

Additional exterior insulation $(\lambda=0.33 \mathrm{~W} /(\mathrm{mK}), 150 \mathrm{~mm})$ and wind retarder of $13 \mathrm{~mm}$ will make the thermal transmittance $\mathrm{U}=0.15 \mathrm{~W} /\left(\mathrm{m}^{2} \mathrm{~K}\right)$ for walls.

After the renovation of the floor (slab on ground) with insulation $150 \mathrm{~mm}$ XPS thermal transmittance will result in $\mathrm{U}=0.17 \mathrm{~W} /\left(\mathrm{m}^{2} \mathrm{~K}\right)$, which is not the best suggested value according to energy performance requirements, but the value is improved compared with the initial about three times. The attic floor can be quite easily improved by replacing the insulation between the beams $(250 \mathrm{~mm})$ and adding extra insulation of $250 \mathrm{~mm}, \mathrm{U}=0.07 \mathrm{~W} /\left(\mathrm{m}^{2} \mathrm{~K}\right)$.

Specific heat loss for building $\Sigma H, W / K$ was estimated (Table 1). Thermal transmittance values for linear thermal bridges are tabulated values from energy efficiency regulation.

Air tightness is an important component in energy efficiency: range of air leakegae rate $q_{50}$ from 1.5 to $10 \mathrm{~m}^{3} /\left(\mathrm{hm}^{2}\right)$ will change the total specific heat loss of the building envelope $97.3 \mathrm{~W} / \mathrm{K}$. If the air leakage rate $\mathrm{q}_{50}=1.5$, specific heat loss caused by infiltration $\mathrm{H}_{\text {air leakage }}=17.2 \mathrm{~W} / \mathrm{K}$ and in case of $\mathrm{q}_{50}=10 \mathrm{~m}^{3} /\left(\mathrm{hm}^{2}\right) \mathrm{H}_{\text {air leakage }}=114.5 \mathrm{~W} / \mathrm{K}$. If base values 3 or $6 \mathrm{~m}^{3} /\left(\mathrm{hm}^{2}\right)$ are used, 34.3 and $68.7 \mathrm{~W} / \mathrm{K}$ will be the results of calculations.

Specific heat loss for the whole building at base value of air leakage $3 \mathrm{~m}^{3} /\left(\mathrm{hm}^{2}\right)$ will be $300.5 \mathrm{~W} / \mathrm{K}$ (Table 1) and delivered energy (Valga, balance temperature 15 C, 3617 degree days) and $67.9 \mathrm{kWh} /\left(\mathrm{m}^{2}\right.$ year). Variation in air tightness will change the values for specific heat loss from through the building envelope 283.3 to $380.6 \mathrm{~W} / \mathrm{K}$ and delivered energy values from 64.1 to $86.1 \mathrm{kWh} /\left(\mathrm{m}^{2}\right.$ year $)$.

Wooden building indicates that there is extra necessity to follow the fire safety requirements. Indoor wooden walls will be preserved and covered with gypsum board. Wooden or metal-stood partitions will be used instead of demolished brick wall and for new partitions. 


\begin{tabular}{|c|c|c|c|c|c|c|c|c|c|c|}
\hline \multirow{2}{*}{$\begin{array}{l}\text { Table } 4 \\
\text { Specific heat loss of } \\
\text { the building envelope }\end{array}$} & \multicolumn{4}{|c|}{ Heat loss through building envelope } & \multicolumn{4}{|c|}{ Heat loss through thermal bridges } & \multicolumn{2}{|c|}{$\begin{array}{l}\text { Heat loss through air } \\
\text { leakage }\end{array}$} \\
\hline & $\begin{array}{ll}\text { Item of } & g \\
\text { envelope } & -\end{array}$ & $\begin{array}{c}U_{i} \\
W /\left(m^{2} \cdot K\right)\end{array}$ & $\begin{array}{l}A_{\mathrm{i}} \\
\mathrm{m}^{2}\end{array}$ & $\begin{array}{l}H_{\text {conduct }} \\
\mathrm{W} / \mathrm{K}\end{array}$ & Thermal bridge & $\begin{array}{c}\Psi_{\mathrm{j}} \\
\mathrm{W} /(\mathrm{m} \cdot \mathrm{K})\end{array}$ & $\begin{array}{l}l_{\mathrm{j}} \\
\mathrm{m}\end{array}$ & $\begin{array}{l}H_{\text {linear' }} \\
\text { W/K }\end{array}$ & Item & Number \\
\hline & Exterior wall & 0.15 & 341.2 & 51.2 & $\begin{array}{l}\text { External corner of } \\
\text { exterior wall }\end{array}$ & 0.30 & 26.2 & 7,9 & $\begin{array}{l}\text { air-leakage } \\
\text { rate } \mathrm{q} 50 \\
\mathrm{~m}^{3} /\left(\mathrm{h} \cdot \mathrm{m}^{2}\right)\end{array}$ & 3.0 \\
\hline & Attic floor & 0.07 & 214.0 & 15.0 & \multirow{2}{*}{$\begin{array}{l}\text { Exterior wall - } \\
\text { ceiling } \\
\text { Exterior wall - } \\
\text { attic ceiling }\end{array}$} & 0.20 & 80.0 & 16.0 & $\begin{array}{l}A_{v p} \text { (building } \\
\text { envelope), } \mathrm{m}^{2}\end{array}$ & 820.0 \\
\hline & Slab floor & 0.17 & 214.0 & 36.4 & & 0.20 & 80.0 & 16.0 & $\begin{array}{l}\text { Number of } \\
\text { floors }\end{array}$ & 2.0 \\
\hline & Door & 1.00 & 4.8 & 4.8 & $\begin{array}{l}\text { Exterior wall - } \\
\text { slab floor }\end{array}$ & 0.30 & 80.0 & 24.0 & $\dot{V}_{\text {inf }}, \mathrm{m}^{3} / \mathrm{s}$ & 0.0285 \\
\hline & \multirow[t]{4}{*}{ Windows } & 1.60 & 46.0 & 73.6 & \multirow{4}{*}{$\begin{array}{l}\text { Junction window } \\
\text { and exterior wall } \\
\text { Junction door and } \\
\text { exterior wall } \\
\text { Exterior wall - } \\
\text { interior wall } \\
\text { Interior corner of } \\
\text { exterior wall }\end{array}$} & 0.10 & 145.2 & 14.5 & & \\
\hline & & & & & & 0.10 & 13.2 & 1.3 & & \\
\hline & & & & & & 0.10 & 65.3 & 6.5 & & \\
\hline & & & & & & -0.20 & 5.2 & -1.0 & & \\
\hline & Total & $H_{\text {conductivity' }}$ & $\mathrm{W} / \mathrm{K}$ & 180.9 & $H_{\text {linear thermal bri }}$ & ridge, $\mathrm{W} / \mathrm{K}$ & & 85.2 & $H_{\text {air leakage, }}, \mathrm{W} / \mathrm{K}$ & 34.3 \\
\hline & \multicolumn{5}{|c|}{ Total specific heat loss of the building envelope } & \multicolumn{5}{|c|}{300.5} \\
\hline & \multicolumn{4}{|c|}{ Average thermal transmittance of the envelope } & velope $\quad \Sigma H / A_{v p}$ & \multicolumn{5}{|c|}{0.4} \\
\hline & \multicolumn{4}{|c|}{ Heated area } & $A_{\text {heated }}, \mathrm{m}^{2}$ & \multicolumn{5}{|c|}{383.9} \\
\hline & \multicolumn{4}{|c|}{$\begin{array}{l}\text { Total specific heat loss of the building envelope } \\
\text { per square metre of heated area }\end{array}$} & $\begin{array}{ll}\text { velope } & \Sigma H / A_{\text {köetav }} \\
& W /\left(\mathrm{m}^{2} \cdot \mathrm{K}\right)\end{array}$ & \multicolumn{5}{|c|}{0.78} \\
\hline
\end{tabular}

The building belongs to Fire Safety class TP3. Fire resistance class for fire protection construction is El30 and will be achieved with using two layers of gypsum board for wooden or metal-stood partitions.

Shrinking population has several outcomes on urban areas. One of them is the prevalence of low quality and underfinanced maintenance housing stock. This results in housing vacancy and abandoned and underused apartment houses. The study shows that buildings can be quite easily revitalized. The main barrier of such revitalization is ownership constrains, not technical issues. Public investments in revitalization of wooden apartment building and creation of municipal apartment stock offer citizens high quality living space and helps or enables to stabilize the population of shrinking towns.

\section{Acknowledgment}

Authors would like to thank alumnus of Tartu College of Tallinn University of Technology Tauri Pai.

Bernt, M. The Limits of Shrinkage: Conceptual Pitfalls and Alternatives in the Discussion of Urban Population Loss. International Journal of Urban and Regional Research, 2014; 40 (2): 441-450. https:// doi.org/10.1111/1468-2427.12289
Bernt, M., Colini, L., \& Foerste, D. Privatization, Financialization and State Restructuring in Eastern Germany: The case of Am Sudpark, International Journal of Urban and Regional Research 2017; 41(4): 555-571. https://doi.org/10.1111/1468-2427.12521 
Bogataj D., McDonnell, D. R., \& Bogataj, M. Management, financing and taxation of housing stock in the shrinking cities of aging societies. Int. J. Production Economics 2016; 181: 2-13. https://doi. org/10.1016/j.ijpe.2016.08.017

Chengbin Deng, C., \& Ma, J. Viewing urban decay from the sky: A multi-scale analysis of residential vacancy in a shrinking U.S. city. Landscape and Urban Planning 2015; 141: 88-99. https://doi. org/10.1016/j.landurbplan.2015.05.002

Elamufondi arendamise investeeringutoetus kohalikele omavalitsustele [Investment support for the development of the housing stock for local governments] http://kredex.ee/toetus/kohalikule-omavalitsusele-2/kov1/15.02.2019

Elzerman, K., \& Bontje, M. Urban Shrinkage in Parkstad Limburg. European Planning Studies 2015; 23(1): 87-103. https://doi.org/10.1080/09654313.2 013.820095

EVS-EN ISO 13370:2017. Hoonete soojuslik toimivus. Soojuslevi pinnasesse. Arvutusmeetodid [Thermal performance of buildings - Heat transfer via the ground - Calculation methods (ISO 13370:2017)] Eesti standardikeskus.

EVS 908-1:2016. Hoone piirdetarindi soojusjuhtivuse arvutusjuhend. Osa 1: Välisõhuga kontaktis olev läbipaistmatu piire. [Guidance for calculation of thermal transmittance of building envelope. Part 1. Opaque building envelope in contact with outdoor-air]. Eesti Standardikeskus.

Großmann, K., Arndt, T., Haase, A., Rink, D., \& Steinführer, $A$. The influence of housing oversupply on residential segregation: exploring the post-socialist city of Leipzig. Urban Geography 2015; 36(4):550-577. https://doi.org/10.1080/02723638.2015.1014672

Haase, A., Bernt, M., Großmann, K., Mykhenko, V., \& Rink D.. Varieties of shrinkage in European cities. European Urban and Regional Studies 2016; 23(1): 86102. https://doi.org/10.1177/0969776413481985

Hollander, J., \& Németh, J. The bounds of smart decline: a foundational theory for planning shrinking cities. Housing Policy Debate 2011; 21(3): 349-367. https://doi.org/10.1080/10511482.2011.585164

Hoone energiatõhususe arvutamise metoodika [Methodology for calculating the energy performance of buildings] https://www.riigiteataja.ee/ akt/119012018007 13.11.2018

Hoone energiatõhususe miinimumnõuded [Requirements for Energy performance], https://www. riigiteataja.ee/akt/119012018006 13.11.18

Jürgenson, L. Elamuehitus. I, Ehitusfüüsika ja -ökonoomika, -materjalid ja põhitarindid "Teaduslik kirjandus"; 1949
Kalamees, T., Arumägi, E., Just, A., Kallavus, U., Mikli, L., Thalfeldt, M., Klõšeiko, P., Agasild, T., Liho, E., Haug, P., Tuurmann, K., Liias, R., Õiger, K., Langeproon, P., Orro, O., Välja, L., Suits, M., Kodi, G., llomets, S., Alev, Ü., Kurik, L. Eesti eluasemefondi puidust korterelamute ehitustehniline seisukord ning prognoositav eluiga [Technical condition and service life of Estonian wooden apartment buildings] Tallinn Technical University Press; 2011.

Kohaliku omavalitsuse üksuse elamufondi arendamiseks juhtumipõhise investeeringutoetuse andmise tingimused ja kord. [Conditions and procedure for granting case-by-case investment support for the development of a local government housing stock] https://www.riigiteataja.ee/ akt/113072018004 15.02.2019

Kotilainen, J., Eisto, I., \& Vatanen, E. Uncovering Mechanisms for Resilience: Strategies to Counter Shrinkage in a Peripheral City in Finland. European Planning Studies 2015; 23(1): 53-68. https://doi.org /10.1080/09654313.2013.820086

Kroll, F., \& Haase, D.. Does demographic change affect land use patterns? A case study from Germany. Land Use Policy 2010; 27: 726-737. https://doi. org/10.1016/j.landusepol.2009.10.001

Liginullenergia eluhooned. Rida- ja korterelamud. http://kredex.ee/public/Uuringud/Liginullenergia_ eluhoonete_tuuplahendused_-_Korter-_ja_ridaelamu_juhend.pdf, KredEx; 2017

Martinez-Fernandez, C., Audirac, I., Fol, S., \& Cunningham-Sabot, E.. Shrinking Cities: Urban Challenges of Globalization. International Journal of Urban and Regional Research 2012; 36(2):213 225. https://doi.org/10.1111/j.1468-2427.2011.01092.x

Pai, T. Valga kesklinna korterelamu rekonstrueerimine munitsipaalkorterelamuks. [Reconstruction of apartment house in central Valga into a municipal apartment house] Master thesis. Tallinn University of Technology, 2015.

Prada-Trigo, J. Local strategies and networks as keys for reversing urban shrinkage: Challenges and responses in two medium-size Spanish cities. Norsk Geografisk Tidsskrift-Norwegian Journal of Geography 2015; 68(4): 238-247. https://doi.org/10. 1080/00291951.2014.923505

Reckien, D., \& Martinez-Fernandez, C. Why Do Cities Shrink? European Planning Studies 2011; 19(8): 1375-1397. https://doi.org/10.1080/09654313.201 1.593333

Ročak, M., Hospers, G., \& Reverda, N. Searching for Social Sustainability: The Case of the Shrinking City of Heerlen, The Netherlands. Sustainlity 2016; 8(4): 1-22. https://doi.org/10.3390/su8040382 
Sousa, S., \& Pinho, P.). Planning for Shrinkage: Paradox or Paradigm. European Planning Studies 2015; 23(1): 12-32. https://doi.org/10.1080/09654313.20 13.820082

Tintera, J., Kotval, Z., Ruus, A., \& Tohvri, E. Inadequacies of heritage protection regulations in an era of shrinking communities: a case study of Valga, Estonia, European Planning Studies 2018, 26 (12): 2448-2459. https://doi.org/10.1080/09654313.201 8.1518409
Wiechmann, T., \& Bontje, M. Responding to Tough Times: Policy and Planning Strategies in Shrinking Cities. European Planning Studies 2015; 23.1: 1-11. https://doi.org/10.1080/09654313.2013.820077

Wiechmann, T. \& Pallagst, K. M. Urban shrinkage in Germany and the USA: A Comparison of Transformation Patterns and Local Strategies. International Journal of Urban and Regional Research 2012; 36(2): 261-280. https://doi.org/10.1111/j.14682427.2011.01095.x

\section{About the} Authors

AIME RUUS

Associate Professor

Tallinn University of Technology, School of Engineering, Tartu College

\section{Main research area}

Building physics, hygrothermal properties of materials

\section{Address}

Puiestee 78 Tartu, 51008

Tel. +3726204805

E-mail: aime.ruus@taltech.ee

\section{JIRI TINTERA}

\section{Lecturer}

Tallinn University of Technology, School of Engineering, Tartu College

\section{Main research area}

Revitalization of urban brownfields

\section{Address}

Puiestee 78 Tartu, 51008

Tel. +3726204805

E-mail: jiri.tintera@taltech.ee 